\title{
CIVIL SOCIETY DI INDONESIA: SUATU KONSEKUENSI LOGIS TERWUJUDNYA GOOD GOVERNANCE
}

\author{
ADRIANI ADNANI \\ STISIPOL Imam Bonjol Padang
}

\begin{abstract}
Civil society is one of the three important sectors of society, along with government and business. Civil society is one of the important elements of the democratization process in Indonesia. In accordance with the problems formulated above, the purposes of this discussion are to find out the description of civil society in Indonesia, and to find out efforts to strengthen civil society as a logical consequence of the realization of Good Governance in Indonesia. The development of civil society involves all aspects and dimensions of life. Therefore, efforts and commitment are needed to strengthen the community. Cooperation is needed because no party, organization, institution or anything even the government can carry it out alone. The relationship between civil society and good governance is symmetrical between the two. This is because the two concepts were born from the concept of democracy that upholds the values of justice, freedom, individual and group rights. Furthermore, democracy requires the state in carrying out its activities to be open to the public. Strengthening civil society in the flow of democracy must be realized as an absolute necessity for the implementation of a 'strong' and 'clean' government. The weakness of civil society in Indonesia is marked by widespread rejections of state/government policies by the people and these rejections have not received a meaningful response from the state/government. In the process of determining policies, the government bureaucracy still feels that citizens are used as objects of policy. This kind of narrow view will make the government anti-suggestions from citizens in determining policies.
\end{abstract}

Keywords: Civil Society, Indonesia, Good Governance.

Abstrak: Masyarakat sipil merupakan salah satu dari tiga sektor penting masyarakat, bersama dengan pemerintah dan bisnis. Masyarakat sipil merupakan salah satu elemen penting dalam proses demokratisasi di Indonesia. Sesuai dengan permasalahan yang dirumuskan di atas, maka tujuan pembahasan ini adalah untuk mengetahui gambaran masyarakat sipil di Indonesia, dan untuk mengetahui upaya penguatan masyarakat sipil sebagai konsekuensi logis dari terwujudnya Good Governance di Indonesia. Pembangunan masyarakat madani melibatkan seluruh aspek dan dimensi kehidupan. Oleh karena itu, diperlukan upaya dan komitmen untuk memperkuat masyarakat. Kerjasama diperlukan karena tidak ada pihak, organisasi, lembaga atau apapun bahkan pemerintah yang dapat melakukannya sendiri. Hubungan antara masyarakat sipil dan pemerintahan yang baik adalah simetris antara keduanya. Pasalnya, kedua konsep tersebut lahir dari konsep demokrasi yang menjunjung tinggi nilai-nilai keadilan, kebebasan, hak individu dan hak kelompok. Lebih jauh lagi, demokrasi menuntut negara dalam menjalankan aktivitasnya terbuka untuk umum. Penguatan masyarakat sipil dalam arus demokrasi harus diwujudkan sebagai kebutuhan mutlak bagi terselenggaranya pemerintahan yang 'kuat' dan 'bersih'. Lemahnya masyarakat sipil di Indonesia ditandai dengan maraknya penolakan terhadap kebijakan negara/pemerintah oleh rakyat dan penolakan tersebut belum mendapat tanggapan yang berarti dari negara/pemerintah. Dalam proses penentuan kebijakan, birokrasi pemerintah masih merasa bahwa warga negara dijadikan objek kebijakan. Pandangan sempit semacam ini akan membuat pemerintah anti saran dari warga dalam menentukan kebijakan. 
Kata Kunci: Civil Society, Indonesia, Good Governance.

\section{A.Latar Belakang Masalah}

Civil society atau masyarakat madani merupakan bentuk masyarakat yang sudah beradab serta maju, baik dalam pemikiran maupun perilaku dalam menyikapi, memaknai, maupun menjalankan kehidupannya. Hal ini tentunya berbeda dengan masyarakat belum maju yang hidupnya cenderung tergantung atau belum mandiri, serta tidak mempunyai inisiatif bagi perkembangan hidupnya. Terbentuknya masyarakat madani tidaklah semudah membentuk suatu kelompok masyarakat. Apalagi di Indonesia terkenal dengan keanekaragaman masyarakat baik itu ras, agama, maupun pemikiran-pemikiran yang berbeda satu sama lain. Oleh karena itu, dibutuhkan pemerintahan negara yang demokratis dan taat pada peraturan perundangan atau hukum yang berlaku. Selain itu, kebijakan politik yang ditetapkan haruslah berorientasi pada pemberdayaan masyarakat secara umum dan merata.

Istilah civil society berasal dari bahasa Latin 'societes civiles' yang mula-mula dipakai oleh Cicero (106-43 SM), seorang orator, politisi, dan filosof Roma. Sejak saat itu sampai dengan abad ke-18, pengertian civil society masih disamakan dengan negara (the state), yaitu sekelompok masyarakat yang mendominasi seluruh kelompok lain. Kemudian, seiring perkembangan waktu pengertian masyarakat sipil (civil society) mulai mengalami perkembangan. Merujuk sejarah perkembangan masyarakat sipil (civil society) di negara-negara barat, banyak ahli di Indonesia menggunakan istilah yang berbeda untuk maksud serupa. Civil society secara umum dipahami sebagai masyarakat sipil yang memiliki peran dan fungsi yang berbeda dengan lembaga negara yang dikenal dewasa ini. Di Indonesia sendiri civil society diartikan sebagai masyarakat madani. Menurut Hikam (2000), masyarakat sipil sebagaimana dikonsepsikan oleh para pemikirnya mempunyai tiga ciri khusus, yaitu: pertama, adanya kemandirian yang cukup tinggi dari individu-individu dan kelompok dalam masyarakat, terutama saat berhadapan dengan negara. Kedua, adanya ruang publik bebas sebagai wahana bagi keterlibatan politik secara aktif dari warga negara demi kepentingan publik. Ketiga, adanya kemampuan membatasi kuasa negara agar tidak intervensionis dan otoriter. Selanjutnya akan kita lihat bagaimana konsep civil society ini diaktualisasikan dalam konteks Indonesia.

Masyarakat madani diartikan sebagai proses penciptaan peradaban yang mengacu kepada nilai-nilai kebijakan bersama. Dalam masyarakat madani, warga negara bekerjasama membangun ikatan sosial, jaringan produktif, dan solidaritas kemanusiaan yang bersifat non negara. Dasar utama dari masyarakat madani adalah persatuan dan integrasi sosial yang didasarkan pada suatu pedoman hidup, serta menghindarkan diri dari konflik dan permusuhan yang menyebabkan perpecahan dan hidup dalam suatu persaudaraan. Civil society adalah salah satu dari tiga sektor penting dari masyarakat, bersama dengan pemerintah dan bisnis. Civil society merupakan salah satu elemen penting dari proses demokratisasi di Indonesia (Nordholt, 2003). Sebagai salah satu elemen yang paling penting dalam proses demokratisasi di Indonesia, kekuatan dan kelemahan dari civil society turut menentukan kecepatan dan kedalaman transisi, yang pada waktunya akan membantu untuk mempertahankan sistem demokrasi itu sendiri.

Wacana mengenai civil society ramai hangat dibicarakan pada pertengahan tahun 90-an saat kekuasaan rezim Suharto mencapai puncak kejayaanya. Pada saat itu, pembahasan tentang civil society menjadi sangat relevan karena dikaitkan dengan sistem pemerintahan yang bersifat otoriter, dimana pada saat itu juga kekuatan negara terlalu besar bila dibandingkan dengan kekuatan rakyat. Civil society kemudian 
dibahas diberbagai seminar-seminar hingga munculah interpretasi tentangnya, sesuai dengan kebutuhan dan kepentingan yang memberi interpretasi. Kondisi pada masa kekuasaan rezim Suharto tentu saja dapat dipandang sebagai bentuk tata kelola pemerintahan yang tidak baik apabila dilihat dari konsep tata kelola pemerinta yang baik, yang kemudian dikenal dengan istilah good governance. Good governance sendiri dapat diartikan sebagai tindakan untuk mengarahkan, mengendalikan, atau mempengaruhi masalah publik (Srijanti, dkk., 2008). Pergeseran pola konfigurasi politik Indonesia dari era otoriter menuju demokrasi yang di awali pasca jatuhnya rezim pemerintahan Presiden Suharto kemudian di isi oleh agenda reformasi yang menguatkan demokrasi sebagai konsep relevan untuk diterapkan dan dikembangkan di Indonesia. Pergesran pola konfigurasi politik tersebut menimbulkan arus gelombang demokrasi besar di Indonesia membuat Indonesia sibuk dengan menata kembali halhal apa saja yang dianggap konsisten dengan semangat demokrasi, perubahan sistem politik, fungsi lembaga-lembaga negara dan lain sebaginya. Perubahan secara struktur tersebut juga diimbangi dengan keinginan rakyat untuk memperoleh hak yang layak sebagai rakyat terhadap negara dengan berbagai pemahaman demokrasi secara praktis maupun secara kontekstual beserta pengaruh asing yang ingin "berpartisipasi" di Indonesia. Dari sudut pandang tersebut penulis mencoba membahas sesuatu yang berkenaan dengan civil society yang ada di Indonesia sebagai konsekuensi logis dari terwujudnya good government.

\section{B.Metodologi Penelitian}

Metodologi penelitian ini akan membahas, hal yang bekaitan dengan latar belakang di atas dapat dirumuskan permasalahan yang dibahas pada tulisan ini, sehubungan dengan civil society yang berkembang di Indonesia. Rumusan masalah tersebut adalah sebagai berikut; 1) bagaimana gambaran masyarakat madani/civil society di Indonesia; dan 2) bagaimanakah upaya penguatan civil society sebagai konsekuensi logis terwujudnya Good Governance di Indonesia? Sesuai dengan permasalahan yang dirumuskan di atas, tujuan dilakukannya pembahasan ini adalah sebagai berikut: 1) Untuk mengetahui gambaran civil society di Indonesia; dan 2) Untuk mengetahui upaya penguatan civil society sebagai konsekuensi logis terwujudnya Good Governance di Indonesia.

\section{C.Hasil dan Pembahasan}

\section{Gambaran Civil Society di Indonesia}

Jauh setelah pemerintahan Soeharto tumbang, pemerintahan ternyata masih berjalan di tempat. Prahara dan krisis seakan enggan menjauh. Indonesia yang tak pernah bisa sepenuhnya bangkit dari hantaman krisis moneter di tahun 1997, terusmenerus harus berhadapan dengan krisis politik, keamanan, sosial, dan yang paling mutakhir ancaman terorisme global. Sejak berakhirnya era Orde Baru, Indonesia telah mengalami beberapa kali pergantian pemerintahan, namun situasi tak kunjung membaik. Rupanya, angin demokrasi yang menerpa Indonesia tak cukup kuat untuk membangun fondasi bagi terbentuknya sebuah good governance. Periode lima tahun yang merupakan kesempatan emas bagi bangsa ini untuk menata dirinya telah berlalu dengan sia-sia. Demokrasi ternyata tak cukup hanya dibangun dengan terpilihnya pemimpin sipil lewat pemilihan umum yang jurdil-jujur dan adil-atau terjungkalnya sebuah pemerintahan otoriter. Demokrasi membutuhkan kepemimpinan politik yang mampu membangun fondasi bagi tegaknya supremasi hukum, terjaminnya hak-hak asasi warga negara, pers yang bebas, dan sistem politik yang memungkinkan checks 
and balances di antara lembaga-lembaga negara (Hikam, 2000). Di sisi lain, demokrasi juga baru bisa berjalan bila masyarakatnya ikut mendukung dan menerapkan prinsipprinsip demokrasi. Dalam kondisi Indonesia saat ini, kedua aspek itu belum muncul.

Selain kepemimpinan politik bangsa ini sangat lemah, masyarakatnya juga baru belajar berdemokrasi, yang menganggap semua persoalan seakan-akan bisa diselesaikan lewat unjuk rasa dan membuat organisasi tandingan. Dengan kata lain, good governance hanya bisa tercipta melalui pemerintahan yang kuat dan terkonsolidasinya masyarakat madani (civil society) yang memosisikan dirinya sebagai penyeimbang negara. Hasilnya, persoalan mendesak yang dihadapi bangsa ini adalah penataan kembali sistem kelembagaan politik, publik, dan sosial kemasyarakatan. Penataan ini harus dibarengi pula dengan pemahaman terhadap pandangan dunia (world-view) terhadap nilai-nilai religius, etika, dan moral dalam diri setiap warga negara. Terkonsolidasinya lembaga politik seperti partai politik, dengan sendirinya menjadi penting karena para anggota parpol inilah yang kelak akan menduduki kursi parlemen dan mengawasi jalannya pemerintahan. Namun, tumbuhnya parpol dalam jumlah besar, dan dangkalnya agenda partai yang hanya terpusat pada perebutan kursi kepresidenan pada akhirnya memunculkan sosok partai yang lemah dan rentan. Kelemahan ini tidak saja mengimbas pada lembaga-lembaga publik yang diduduki mereka, tetapi juga dalam kultur dan perilaku politiknya.

Suatu ide sosial politik memerlukan prasarana sosial kultural untuk dapat terwujud. Di sinilah peran masyarakat madani harus diberdayakan. Indonesia beruntung memiliki organisasi seperti Muhamamdiyah dan Nahdlatul Ulama yang telah menjadi aktualisasi Civil Islam (Islam Kewargaan) terpenting dalam masyarakat dan bangsa Indonesia. Kedua organisasi ini telah memberikan kontribusi besar dalam menghasilkan better ordering of society (masyarakat yang lebih teratur) melalui berbagai usaha dan program dalam bidang pendidikan, keagamaan, pelayanan sosial, dan ekonomi. Jejak ini yang seharusnya terus ditumbuhkembangkan dan digalang kebersamaannya oleh ratusan Ormas maupun LSM yang dimiliki negeri ini. Proses reformasi memang lambat dan tertatih-tatih, tetapi kita menyadari bahwa bangsa ini telah berada di point of no return. Jika eksperimentasi sekarang ini kembali gagal, itu berarti penundaan untuk kesekian kalinya bagi pelaksanaan demokrasi di Indonesia. Mengutip komentar Nurcholish Madjid, jika merujuk pengalaman di masa lalu, dibutuhkan tenggang waktu satu generasi untuk tibanya sebuah kesempatan baru bagi eksperimen demokrasi di negeri kita.

Penggunaan istilah masyarakat madani dan civil society di Indonesia sering disamakan atau digunakan secara bergantian. Hal ini dirasakan karena makna di antara keduanya banyak mempunyai persamaan prinsip pokoknya, meskipun berasal dari latar belakang sistem budaya negara yang berbeda. Dua penggunaan istilah civil society dari sudut konsep sosiologis, yaitu dalam tingkatan kelembagaan dan organisasi sebagai tipe sosiologi politik dan membuat civil society sebagai suatu fenomena dalam dunia nilai dan kepercayaan. Untuk yang pertama, civil society dijadikan sebagai perwujudan suatu tipe keteraturan kelembagaan. Dalam pengertian ini, civil society dijadikan jargon. Sedangkan yang kedua, civil society menjadi wilayah kajian filsafat yang menekankan pada nilai dan kepercayaan. Pembangunan civil society menyangkut seluruh aspek dan dimensi kehidupan. Karena itu, diperlukan upaya dan komitmen untuk menguatkan masyarakat. Kerjasama diperlukan karena tidak ada fihak, organisasi, lembaga atau apapun bahkan pemerintah sekalipun yang dapat melaksanakannya sendirian. 


\section{Upaya Penguatan Civil Society Sebagai Konsekuensi Logis Terwujudnya Good Governance}

Beragam interpretasi tentang wacana civil society terus berkembang. Culla (1999) menjelaskan bahwa civil society jika dipadanankan ke dalam bahasa Indonesia maka akan dijumpai kata padananya seperti masyarakat madani masyarakat warga, atau masyarakat kewargaan, masyarakat sipil, masyarakat beradab, atau masyarakat berbudaya. dalam bahasa indonesia istilah "society" diartikan dengan "masyarakat". Civil society ada juga yang mengartikannya dengan masyarakat berbudaya (civilized society) lawannya adalah 'masyarakat liar' (savage society). Mendekati pengertian masyarakat berbudaya, terjemahan lain yang juga sering digunakan adalah masyarakat madani.

Istilah civil society juga terkadang diterjemahkan secara gamblang sebagai masyarakat sipil. Usman (2001) menegaskan bahwa yang harus digaris bawahi adalah civil society merupakan sebuah konsep yang penting, yaitu terdapatnya keinginan dan tuntutan untuk membangun masyarakat yang mampu berkreasi secara maksimal, mampu menyerap nilai-nilai demokrasi secara konkrit, dan harapan akan terciptanya sistem politik dan pemerintahan demokratis dari waktu ke waktu. Karena itu, salah satu ide penting yang melekat dalam konsep civil society adalah keinginan memperbaiki kualitas hubungan antara masyarakat dengan institusi sosial yang berada pada sektor publik (pemerintah dan partai politik), sektor swasta (pelaku bisnis), dan sektor sukarela (lembaga swadaya masyarakat, organisasi keagamaan dan kelompok profesional).

Relasi civil society dan Good Governance merupakan suatu hal yang simetris diantara keduanya. Hal ini disebabkan kedua konsep tersebut terlahir dari konsep demokrasi yang menjunjung tinggi nilai-nilai keadilan, kebebasan, hak individu maupun kelompok. Lebih jauh lagi, demokrasi mengharuskan negara dalam melakukan kegiatannya untuk bersikap terbuka kepada publik. Hal ini sebagai bentuk tuntutan dalam membangun Good Governence di sebuah negara demokrasi. Artinya bahwa negara dalam penyelenggaraan pemerintahannya harus bersikap terbuka sehingga publik/masyarakat sipil dapat secara mudah untuk mengakses informasi terkait dengan penyelengaraan pemerintahan tersebut.

Realitas demokrasi di indonesia, perubahan pola kekuasaan sentralistik ke pada pola kekuasaan disentralisasi demi tercapainya good governence di tingkatan daerah yang diawali oleh Undang-Undang Nomor 22 Tahun 1999 kemudian diperjelas melalui Undang-Undang Nomor 32 Tahun 2004 tentang Pemerintahan Daerah, ternyata belum dapat menjawab hakikat good governance di tingkat lokal ataupun nasional. Problematika kemudian muncul di masa disentralisasi yang memiliki kemiripan dengan problematika dimasa sentralistik. Kekuatan-kekuatan lokal menggantikan posisi kekuatan kekuatan pusat. Walaupun kekuatan lokal telah menghegemoni pemerintahan di tingkat lokal, ternyata belum dapat menjamin kepuasan masyarakat di tingkat lokal dalam pemenuhan hak maupun tuntutannya terhadap tercapainya pemerintahan yang bersih, transparan atau dikenal dengan istilah Good Governance. Esensi dari pada undang-undang otonomi daerah dengan meringkas pemikiran pakar otonomi daerah "M. Ryaas Rasyid" dalam Said (2007) tentang hakekat pengubahan praktek pemerintahan yang sentralistik ke pemerintahan yang desentralisasi adalah pemerintahan daerah jauh lebih independen dalam memilih pemimpin mereka, memajukan kepentingan mereka, mengembangkan institusi mereka, dan memobilisasi dukungan-dukungan dari masyarakat-masyarakat mereka sendiri. 
Pada tinggatan lokal saat ini masih dapat dijumpai penyelenggara pemerintah yang bersifat tertutup terhadap informasi penyelenggaraan pemerintahan. Gejala seperti ini di gambarkan model perencanaan pembangunan sebagaimana diamanatkan Undang-Undang Nomor 25 Tahun 2004 tentang Sistem Perencanaan Pembangunan Nasional yang memungkinkan keterlibatan masyarakat yang semakin besar. Pengakomodasian partisipasi masyarakat ini diasumsikan agar perencanaan yang disusun akan sesuai dengan kebutuhan masyarakat. Sayangnya, proses perencanaan tersebut masih belum terintegrasi dengan proses penganggaran. Proses perencanaan yang relatif partisipatif tereduksi oleh potret APBD yang tidak aspiratif. Indikasi dari ketidaksesuaian antara proses perencanaan dan penganggaran ini dapat dibuktikan dari hilangnya usulan-usulan prioritas hasil Musrenbangdes saat masuk di Musrenbang di tingkat berikutnya.

Potret diatas tentu sangat bertentangan dengan prinsip demokrasi dalam mewujudkan good governence. Masarakat sipil atau civil society memiliki hak untuk mendapatkan informasi dan partisipasi dalam penyelenggaraan pemerintahan di tingkat lokal maupun nasional karena masyarakat merupakan bahan bakar dari pergerakan pembangunan bangsa dan retribusi penyelenggaraan pembangunan juga berasal dari uang rakyat. Pemerintah sebagai pemilik birokrasi tentulah harus bekerja demi kepentingan publik. Ketidaksesuaian antara negara/penyelenggara pemerintahan dan masyarakat sipil/civil society akan menyebabkan pembangunan berjalan tidak pada semestinya, baik pada persoalan skala prioritas kebutuhan maupun pada persoalan kualitas penggunaan anggaran yang baik.

Untuk mencapai good governance maka dibutuhkan pilar-pilar penyanggah bagi tercapainya tujuan good governance tersebut, yakni: pemerintah (the state), civil society (masyarakat adab, masyarakat madani, masyarakat sipil), dan pasar atau dunia usaha. Civil society mau tidak mau harus dapat bertahan dalam upaya mengawal penyelenggaraan pemerintahan yang baik pada saat diminta maupun tidak. Hal ini penting karena menyangkut wilayah kehidupan publik. Jika penyelenggara pemerintah tidak dapat mencerminkan sikap yang akomodatif dan komunikatif maka gagasan bahwa perubahan harus direbut, tidak dapat ditunggu secara pasif.

\section{D.Penutup}

Penggunaan istilah masyarakat madani dan civil society di Indonesia sering disamakan atau digunakan secara bergantian. Hal ini dirasakan karena makna diantara keduanya banyak mempunyai persamaan prinsip pokoknya, meskipun berasal dari latar belakang sistem budaya negara yang berbeda. Hal yang perlu diperhatikan dalam upaya membangun masyarakat madani di Indonesia yaitu; kebhinekaan masyarakat, terselenggaranya kehidupan yang demokratis baik dalam kehidupan bermasyarakat dan berbangsa, dimana hak-hak warga negara diakui dan dilindungi, baik oleh aparat maupun oleh masyarakat sendiri. Penguatan civil society dalam arus demokrasi harus disadari menjadi kebutuhan mutlak bagi terselenggaranya pemerintahan yang 'kuat' dan 'bersih'. Lemahnya civil society di Indonesia, ditandai dengan maraknya penolakan-penolakan terhadap kebijakan negara/pemerintah oleh rakyat dan penolakan tersebut tidak mendapat respon berarti dari negara/pemerintah. Pada proses penentuan kebijakan birokrasi pemerintah masih merasa bahwa warga masyarakat dijadikan sebagai objek dari kebijakan. Pandangan sempit semacam ini akan membuat pemerintah menjadi anti terhadap usulan-usulan warga masyarakat dalam penentuan kebijakan. 


\section{Daftar Pustaka}

Culla, Adi Suryadi. 1999. Masyarakat Madani; Pemikiran, Teori, dan Relevansinya dengan Cita-Cita Reformasi. Jakarta: Raja Grafindo Persada.

Hikam, Muhammad A.S. 2000. Islam, Domokratisasi, dan Pmberdayaan Civil Society. Jakarta: Erlangga.

Nordholt, Nico Schulte. 2003. "Civil Society". Papper of University of Twente, Enschede, Holland.

Republik Indonesia. 1999. Undang-Undang Nomor 22 Tahun 1999 tentang Pemerintahan Daerah". Jakarta.

. 2004. "Undang-Undang Nomor 25 Tahun 2004 tentang Sistem Perencanaan Pembangunan Nasional". Jakarta. . 2004. Undang-Undang Nomor 32 Tahun 2004 tentang Pemerintahan Daerah”. Jakarta.

Said, M.Mas'ud. 2007. Birokrasi di Negara Birokratis. Malang: UPT Penerbitan Universitas Muhammadiyah Malang.

Srijanti, dkk. 2008. Etika Berwarganegara. Jakarta: Salemba Empat.

Usman, Sunyoto. 2001. "Membangun Kemitraan antara Pemerintah dan Masyarakat Madani untuk Mewujudkan Tata Pemerintahan yang Baik". Disampaikan pada Seminar Badan Perencanaan Pembangunan Nasional, Jakarta, 9 Oktober 2001. 